\title{
最近の歯学
}

\section{4. 歯科矯正}

\section{顎運動パターン解析と矯正診断}

\section{東京医科歯科大学歯学部歯科矯正学教室 新 内 秀 一}

不正咬合の診断ならびに治療方針の決定にあたって は, 咬合系の機能的な不調和に起因する不正を明確に把 握する必要がある。この点に関して従来行われている方 法は, いずれも顎運動時のある一時点をとらえた分析法 であり，しかもその評価は主観的判断に依存する面が強 かった。この種の運動の診査にあたってはまず再現性の 良い安定した運動の記録を行い，それに基ついた生理的 顎運動全体の解析が必要となってくる。

著者は X-Y tracker を利用した新しい顎運動記録装 置 ${ }^{1)}$ を用い混合歯列期にある不正咬合者に 1.0 秒， 0.8 秒 および 0.6 秒を 1 回の運動サイクルとする習慣性開閉運 動を行わせ，正中矢状面に拈ける運動路パターンの特徵 を抽出した2)。

図 1 は，習慣性開閉運動路の軌跡(図 $1-\mathrm{a})$ ，この 垂直成分をペンレコーダー上に描記した（図 1-b) 場合 の模式図である。この曲線(図 1-b) の開口路, 閉口路 の䙲長を10等分し各 segment ごとに $\mathrm{V}_{\mathrm{i}}=\frac{\mathrm{y}_{\mathrm{i}}}{\mathrm{t}_{\mathrm{i}}}$ を求め た。各 segment のV V 值の総和に対するそれぞれの segment のVの百分率を求め, これを運動速度を表す Index (I ) とした。水平成分についても同様の手法によ りIndex を求めた。

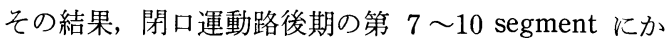
けて，極端な Index の低下をみる症例と示さない症例
に大別できた。図 2 は，1.0 秒サイクルに打いて Index の極端な低下を示した症例（図 2-a) と示さなかった症 例(図 2-b) の 1 例をグラフにしたものである。運動速 度 Index の極端な低下を示す症例の数は, サイクルを 早めることにより減少した。閉口運動の後期において垂 直成分の運動速度 Index が極端に低下した segment で は, 同椂に水平成分の運動速度 Index も低下しており, このことは閉口路後期において顎運動自体が極端に遅く なる現象を把握したもので，早期接触等の障害の存在を 示唆していると思われる。そこで, 従来機能的不正咬合 の診断に使用されている神山の機能分析法, Moyers の ワックスバイト法を用いて検討してみると，閉口路後期 において運動速度 Index の極端な低下を示す症例につ いては機能的要因の介入が示唆された。このことは, 従 来から主観的判断に依存する面の強い不正咬合の機能的 診断法に対して，運動速度 Index は客観的立場から同定 を下すきわめて有効な手法であることを示しているもの と考兄らる。

\section{文献}

1）三浦不二夫, 近藤勝義 : 新しい顎運動解析装置 について. 口病誌, $45: 682-689,1978$.

2）新内秀一: 混合歯列期に拟兴顎運動パターン の観察. 口病誌, $46: 306-322,1979$.

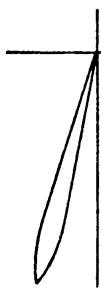

(a)

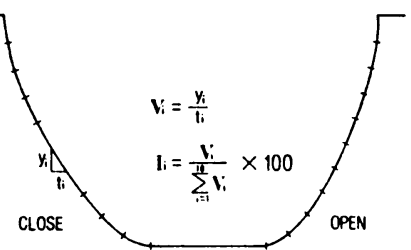

(b)
図 1

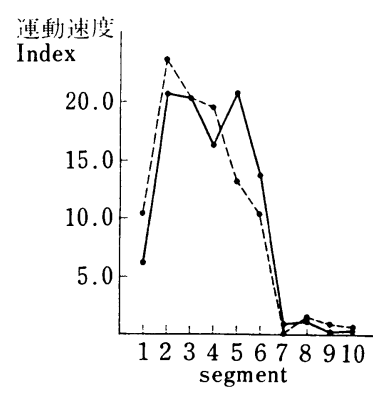

(a)

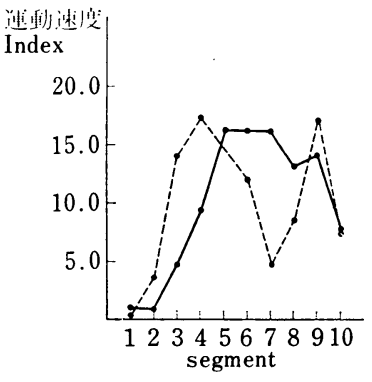

(b)

— 垂淔成分の速動速度 Index 水平成分の速動速度 Index 